\title{
LA MEMORIA FABULADA Y LA ESCRITURA DE EDUARDO MENDOZA
}

\author{
María José García-Rodriguez \\ Universidad de Murcia \\ Murcia, España \\ mariajose.garcia24@um.es
}

\section{RESUMEN / ABSTRACT}

El presente artículo tiene como objetivo explicar la trascendencia que la memoria, como procedimiento imaginativo, tiene en la teoría y creación literaria, para lo cual se ha acuñado el sintagma de "memoria fabulada" como noción crítica. El estudio de la dialéctica de memoria e imaginación, presente en el pensamiento filosófico desde los tratados clásicos, logra evidenciar no solo las consecuencias de esta dicotomía y su estrecha relación con lo literario, sino también la apremiante necesidad de reconsiderarla en el difuso marco de la posmodernidad y las escrituras del yo. En concreto, la literatura de la Transición española ha surgido como una de las que con mayor elocuencia explora la paradoja de la memoria fabulada, y así se ha querido demostrar a través del análisis de la obra ficcional, ensayística y paratextual de uno de sus representantes: Eduardo Mendoza.

PALABRAS ClaVE: reminiscencia, fabulación, figuración, imaginación, posmodernidad.

\section{FABLED MEMORY AND EDUARDO MENDOZA'S WRITING}

This work aims to explain the transcendence of memory, understood as an imaginary process, in the literary theory and creation. In doing so, we came up with the term "fabled memory" to develop a critical analysis. By studying the dialectic of memory and imagination, which has been present in the philosophical thought since the first classical treatises, it can be evinced not only the consequences of that dichotomy and its close relationship with literature, but also the compelling need of reconsidering it in the dim field of Postmodernism and the writings of the self. Specifically, the Spanish Transition Literature has emerged as one of the most eloquent about the paradox of the fabled memory. Thus, it is demonstrated here through the review of the fictional, essayistic, and paratextual oeuvre of one of its principal writers: Eduardo Mendoza.

KEYWORDS: reminiscence, fabulation, figuration, imagination, postmodernism. 
El mundo narrativo de Eduardo Mendoza acoge un abanico estético rico en matices coloristas desde el punto de vista de fondo y forma, que se ha proyectado en la bibliografía académica sobre el autor. Dada la heterogeneidad que caracteriza los textos de y sobre Mendoza, determinar cuál es la pieza que mueve la maquinaria de su literatura es una tarea difícil de abordar. Sin embargo, se dilucida en las investigaciones que se acercan a la obra del barcelonés desde muy distintos objetivos, una comunicación, con mayor o menor evidencia, en la introducción de lo histórico como el cuadro de enfoque de la mirada mendociana. Ya sea desde el espacio, el tiempo o la construcción discursiva, las referencias a lo histórico, entendido como el pasado nacional, social y artístico, parecen ineludibles para el análisis de la obra del autor. Él mismo afirma en el prólogo a La ciudad de los prodigios (1986) su propósito de "novelar la historia" (4) al que remitirán los distintos enfoques críticos. No obstante, este estudio pretende demostrar que, aun comportándose como uno de los elementos conformantes (aunque más como concepto abstracto que como aparato referencial), no es lo histórico la pieza clave que sostiene toda la narrativa -novelística, teatral y ensayística- de Mendoza, sino otro elemento escasamente percibido: la memoria.

La memoria es el trasfondo que se ha venido intuyendo en las investigaciones sobre la narrativa del autor, sobre todo a propósito de la desviación de lo que comprende la noción de "memoria histórica". Dicho esto, aparecen comentados matices distintos que exceden el historicismo y aluden, por ejemplo, a la visualidad de las imágenes quedan grabadas en la memoria del lector a la manera cinemática, como momentos fotográficos instalados en el recuerdo (Bou). También se ha revisado la intervención de la memoria colectiva en el estudio sobre la revisitación neomoderna al pasado (Navajas), la deformación cómica de personajes históricos advertida (Saval, La ciudad), o la consideración de la historia como pretexto para la intertextualidad (Soubeyroux). Pero, de entre todas, merece ser citada en este contexto la siguiente observación de Aparicio Maydeu: "Una trilogía consagrada a la construcción de la historia social y moral de la ciudad de Barcelona, a la creación del simulacro de su memoria colectiva" (56, la cursiva es nuestra). Estos son solo algunos ejemplos de textos críticos en los que asoma una presencia latente que, no obstante, se aborda generalmente en la bibliografía académica desde una mirada histórico-referencial, propiciada por el juego de memoria, consenso y olvido que determinan la denominada literatura de la Transición (Santana), en la que se inscribe buena parte de la obra del 
barcelonés ${ }^{1}$. Pero si a la conjugación de todas las ideas espigadas en distintos estudios, como semillas sin desarrollar, se integra la voz fecunda del propio autor, las raíces sobre las que crece el mundo narrativo de Eduardo Mendoza en toda su complejidad se agarran a un terreno singular de la memoria. Pues, parafraseando las palabras del novelista, no se trata de la memoria entendida comúnmente en los análisis literarios como recapitulación de sucesos acontecidos, sino la memoria como proceso de fabulación:

Cuando un autor relee una novela que escribió muchos años atrás, es inevitable que ese ejercicio se convierta en una reflexión sobre la memoria. Quizá todas las novelas lo son, quiera o no quien las escribe. Cuando hablo de memoria no me refiero a lo mismo que habitualmente entendemos por ese término, sobre todo en el terreno de la recreación literaria: un recuento más o menos preciso de unas vivencias personales, tan glaseadas como se quiera, pero en definitiva encuadradas en el tiempo y el espacio [...] es un catálogo desordenado de voces $[. .$.$] voces tan variadas como coloristas: unas engoladas, casi$ temibles; otras cantarinas; unas procedentes de medios mecánicos casi milagrosos, como la radio o el cine; otras, las más, voces vivas que invadían con desparpajo el espacio privado desde la calle o el patio de vecinos, cuando el ruido del tráfico era poco y las ventanas estaban abiertas de par en par. Unas voces que revelaban el origen, la condición, la edad y el humor de las personas, antes de que la televisión las homologara (Mendoza, Una comedia 646-647).

En estas líneas se recapitulan, casi sin querer (como aparentemente siempre ocurre con Mendoza), las pautas y las intenciones creativas que marcan su obra: la ambigüedad de las referencias, la multiplicidad discursiva, la riqueza intertextual y el carácter revelador del lenguaje. Su escritura siempre se encamina hacia la elaboración de lo que podemos llamar una imagen de época, de un lenguaje que retrate un espacio y un tiempo gracias a su poder evocador, no a su fidelidad referencial. En distintos momentos el autor ha señalado un interés

\footnotetext{
De hecho, la memoria aparece como un lugar común al que vuelven los estudios sobre escritores próximos a Mendoza, especialmente Vázquez Montalbán (Saval, El triunfo; Colmeiro), Luis Mateo Díez, (Díez; Pozuelo Yvancos, “Celama”) o José María Merino (Álvarez Méndez). La guerra civil y la dictadura funcionan en los territorios del hispanismo literario como dispositivos fundamentales de las escrituras del pasado contemporáneo.
} 
costumbrista con el que distanciar su discurso de los objetivos puramente sociales que en no pocas ocasiones le son atribuidos. Por todo ello, creemos que, en último término, la literatura de Eduardo Mendoza no existe para ser leída desde la referencialidad histórica, sino desde la figuración del recuerdo. $Y$ es precisamente esta consciencia a la hora de construir mundos ficcionales la que otorga a sus textos la atemporalidad de la buena literatura: no hay un afán de reproducción de voces y estilos sociohistóricos -siempre perecedera y rápidamente acartonada- sino la búsqueda de una construcción discursiva que, sin serlo, evoca (y, con ello, revela). La memoria como fabulación de figuraciones evocadoras, esto es, la "memoria fabulada" se convierte en el material y el método de la escritura de Eduardo Mendoza.

Con el sintagma de "memoria fabulada" pretendo adoptar un concepto que conjugue la dialéctica de memoria e imaginación, que se retrotrae en realidad a los orígenes mismos del pensamiento filosófico occidental, pero que deviene fundamental para la teoría de la literatura contemporánea. Fabulada en tanto que figuración, la memoria comparte los métodos de la fantasía y la imaginación, presentándose como una fórmula de creación fantasmática construida sobre la evocación. La idea misma de figurar es aquella que fundamenta el funcionamiento de lo literario, que no es sino la forma verbal de figurar(se) algo o alguien (incluido un yo-otro ${ }^{2}$ ) para construir un universo discursivo entre los posibles. Y lo mismo ocurre en el caso de la memoria, que según el Diccionario de Autoridades, es "una de las tres potencias del alma, en la qual se conservan las especies de las cosas passadas, y por medio de ella nos acordamos de lo que hemos percibido por los sentidos [...] donde los espíritus vitales imprimen las imágenes o figuras de los objetos que entran

2 En sus investigaciones sobre las escrituras del yo, Pozuelo Yvancos se sirve precisamente de la noción de figuración en busca de una justa delimitación de las nuevas narrativas que se han venido recogiendo a la sombra del término "autoficción". La distinción a propósito de las proyecciones del yo es reveladora en sus estudios, pues aborda en ellas la problemática surgida de la flexibilidad de los límites entre lo ficcional y lo biográfico, a partir de la profundización en la epistemología de los conceptos de figuración, imaginación y fantasía, trayendo a colación las teorías platónicas y aristotélicas. En este punto merece ser citada una breve pero muy significativa reflexión sobre la idea de fantasía en Platón: "la idea de pintura o figuración, que es por tanto secundaria, se asemeja a una representación construida a partir de esas sensaciones; y mejor habría sido decir a partir de la memoria de esas sensaciones, porque en Platón es muy importante el vínculo entre las imágenes o phantasmata (figuraciones) y la memoria, por cuanto todo esto le ocurre al hombre "dentro de sí", como una facultad del alma" ("Figuración" 164). 
por los ojos o por los oídos" (párr. 1). Con esta definición se evidencian las conexiones conceptuales entre la invención literaria y la rememoración, mecanismos ambos forjados en la construcción de imágenes, esto es, de figuraciones. El diálogo establecido entre estos dos lugares, estos almacenes de impresiones, iniciado desde las teorías platónicas y aristotélicas, abrió las vías de reflexión que han acogido la fenomenología, la ética o la historia, y sobre las cuales han girado ciertas consideraciones de lo fantástico en las que es necesario insistir.

Siguiendo la estela de la filosofía escolástica, la imaginación -adoptando el término latino- se reconoce como el lugar del alma en el que se guardan las imágenes producto de las impresiones en ella grabadas, donde el terreno de la memoria aparecerá como un lugar construido sobre las improntas dejadas por los sentidos de una experiencia vital. Esta identificación de la imaginación y la fantasía como categorías espaciales perdura a lo largo de la historia de la literatura. Sin ir más lejos, el trastorno sobre el que siguen corriendo ríos de tinta tiene su origen precisamente en la perturbación de dichos lugares, en los que "llenósele" y "asentósele" toda una tradición caballeresca que enfrascó a don Alonso Quijano. Resolver la ambigüedad quijotesca requeriría dar respuesta a la conciencia o inconciencia de las demarcaciones de la invención, que permitirían discernir entre lo discursivo (imaginario) y la historia (memoria), y que determinarían la sinceridad o el fingimiento del personaje. La complejidad de establecer un diagnóstico se agudiza en la ligereza de los lindes entre lo visto y lo imaginado, que en muchos casos se proyecta a su emplazamiento en la memoria y/o en la fantasía. Así, bien como recuperación espaciotemporal (memoria), bien como voluntad estética (imaginación), memoria e imaginación comparten la categoría de lenguajes figurados, cómplices en la creación y manipulación de imágenes y textos. Recurridas son las metáforas platónicas de la plancha de cera regalada por Mnemosina del Teeteto y el pintor del Filebo, que intentan dar respuesta a los procesos llevados a cabo en la imaginación para acceder al recuerdo:

Supón conmigo, siguiendo nuestra conversación, que hay en nuestras almas planchas de cera. [...] Decimos que estas planchas son un don de Mnemosina, madre de las musas, y que marcamos en ellas como con un sello la impresión de aquello de que queremos acordarnos entre todas las cosas que hemos visto, oído o pensado por nosotros mismos, estando ellas dispuestas siempre a recibir nuestras sensaciones y reflexiones; que conservamos el recuerdo y el conocimiento de lo que está en ellas grabado, en tanto que la imagen subsiste (Platón, 
Teeteto 191d).

Acepta también que haya al mismo tiempo otro artesano en nuestras almas. [...] Un pintor, que después del escribano traza en las almas las imágenes de lo dicho (Platón, Filebo 39b).

Con las acciones de imprimir y pintar se evidencian los dos elementos que distorsionan la demarcación entre memoria e imaginación: la presentificación de lo ausente y la naturaleza dual de la figuración. A partir de la teoría de la eikon platónica y su reflexión acerca de su ser-representación de lo ausente, la discusión sobre la fantasía queda enmarcada en la memoria y, al mismo tiempo, la memoria se vuelve una región de la fantasía: recorrerla es palpar aquellas figuras depositadas que tienen valor de tiempo, de pasado ${ }^{3}$, pero cuya imagen no deja de ser una impresión a la que solo se puede llegar por los caminos de la imaginación. Ambas gestarán sus imágenes en la opinión (doxa) de aquello percibido por los sentidos y de ahí emerge una dicotomía común: "Cuando uno, tras separar de la visión o de alguna otra sensación lo entonces opinado y dicho, ve de algún modo, en sí mismo las imágenes de lo opinado y dicho. ¿O no ocurre esto así en nosotros?” (Platón, Filebo 39c). A esta esquematización, contestará Aristóteles:

¿qué es lo que uno recuerda, la afección presente o el objeto que dio origen a ella? Si lo primero, entonces no recordaríamos nada una vez ausente; si lo otro, ¿cómo podemos, percibiendo la afección, recordar el hecho ausente que no percibimos? Si hay en nosotros algo análogo a una impresión o una pintura, ¿por qué razón la percepción de esto será memoria o recuerdo de algo distinto y no de esto mismo? Pues es esta afección lo que uno considera y percibe, cuando ejercita su memoria. ¿Cómo, pues, se recuerda lo que no es presente? ("De memoria" 450a).

De la oposición presencia/ausencia derivan pues las reflexiones platónicas y aristotélicas que nos legan los diálogos socráticos a propósito de la figura donde la interdependencia entre memoria e imaginación queda constituida:

Es con Aristóteles que se concretará la distinción temporal en la definición del recuerdo. En "De la memoria y la reminiscencia" se encuentra la especificidad de la función temporalizadora de la memoria, que "no es ni una sensación ni un juicio, sino un estado o afección de uno de los dos cuando ha pasado el tiempo" (449b25). 
"¿qué sucede con el enigma de una imagen, de una eikon -hablando en griego con Platón y Aristóteles- que se muestra como presencia de una cosa ausente marcada con el sello de lo anterior?" (Ricoeur 14). La memoria, la historia, el olvido (2003) arranca con una lúcida discusión sobre la memoria y la imaginación en la que Paul Ricoeur hace conversar a Aristóteles y Platón con Agustín, Locke o Husserl, lanzando esta interrogante que vertebrará su ensayo y que incide directamente en nuestra idea de memoria fabulada ${ }^{4}$. Nos enfrentamos a una dualidad compartida entre imagen-imaginado y recuerdo-recordado, dos formas de figuración que, diferenciadas por la nota de temporalidad, se subordinan en ambos casos a la subjetividad de hacer presente lo percibido y opinado. Y es que, pese a las concreciones que desde la propuesta aristotélica han establecido distintos tipos y categorías de imágenes de la memoria, lo cierto es que la subjetividad que involucra ese traer a la memoria experiencias percibidas (impresas) continúa acercándola al acto de imaginar; una proximidad sobre la que ha razonado la historia de la filosofía y que ha dejado discursos germinativos para la creación literaria, como el que sigue de san Agustín en respuesta a la carta de Nebridio sobre fantasía, memoria e inteligencia:

en ambas clases la memoria retiene el tiempo pasado, ya que recuerdo a aquel hombre y a esa ciudad porque los vi, no porque los veo. [...] Veo que todas estas imágenes, que tú llamas fantasías como otros muchos, se distribuyen con la mayor comodidad y verdad en tres géneros: el primero es impresión de cosas sentidas; el segundo, de cosas opinadas; y el tercero, de cosas racionales (cit. en Cilleruelo 48).

Es este acercamiento a lo imaginado, estos "géneros de memoria", lo que origina la existencia de aquello que hemos tenido a bien de llamar "memoria fabulada", en un intento por (des)cubrir este "punto ciego" -acudiendo al elocuente ensayo de Cercas- que provoca la inestable relación entre presencia/ausencia, invención/reminiscencia e imagen/imaginado de todo

4 Es significativo advertir la presentación que de esta obra por Ricoeur como un retorno a las "lagunas" dejadas en las problemáticas tratadas en ambas Tiempo y narración (1987) y Sí mismo como otro (1990), una conjugación de las investigaciones derivadas del discurrir temporal y la reflexividad, la disociación y alteridad del sujeto, esto es, de las fórmulas figurativas de la narración. 
acto de figuración, incluyendo el literario. Según Ricoeur, sería esta aporía la que permite al Quijote, viendo en su imaginación lo que no veía ni había, convertirse en el centro mismo de reflexión de la literatura moderna y la novela como género.

La dualidad presente/ausente o sello/impronta, que ha situado a la memoria en el terreno de la imaginación y se sostiene sobre el mencionado acto de figuración, solo será posible gracias a la capacidad evocadora de la imagen. En otras palabras, la figuración, sea en el terreno de la memoria, sea en el de la imaginación, se origina en la potencial asociación que se crea entre elementos. En este punto, la teoría platónica nos ofrece los dos tipos de asociaciones que, a su vez, darían a luz dos vías artísticas: aquella susceptible de veracidad (eikastica) y la ligada a propósitos falaces (phantasmatica). Como se puede colegir, de ellas depende -además de la legitimidad de permanencia o expulsión de la República- la distinción de las formas afincadas en la imaginación de aquellas de la memoria. Es a partir de la diferenciación platónica que Paul Ricoeur anotará un elemento al que hemos de remitir por su trascendencia en nuestro objeto de estudio:

Si se puede criticar a la memoria su escasa fiabilidad, es precisamente porque es nuestro único recurso para significar el carácter pasado de aquello de lo que declaramos acordarnos. Nadie pensaría en dirigir semejante reproche a la imaginación, en la medida en que ésta tiene por paradigma lo irreal, lo ficticio, lo posible y otros rasgos que podemos llamar no posicionales. La ambición veritativa de la memoria tiene propiedades que merecen ser reconocidas [...]. Para decirlo sin miramientos, no tenemos nada mejor que la memoria para significar que algo tuvo lugar, sucedió, ocurrió antes de que declaremos que nos acordamos de ello (La memoria 40-41).

La distinción de la memoria y la imaginación establecida sobre la intencionalidad -la "ambición veritativa" de la memoria- trae consigo dos evidencias: el indulto a la imaginación respecto a la veracidad y la función semiológica de la memoria como garantía de pasado. El debate iniciado con Platón y Aristóteles resulta por lo tanto fundamental para la teoría literaria en la actualidad, pues será, junto a los enfoques pragmáticos, el que puede arrojar luz a los lugares que la posmodernidad está oscureciendo. La necesidad de contar con la memoria como creación así como de fijar en ella el epíteto de la fabulación se nos revela decisiva. Evocación, asociación, creación: son estos tres elementos los que protagonizan las teorías sobre el funcionamiento 
de la memoria y, de igual forma, los elementos que definen la creación estética. Lo que busco es ponderar los trasvases que se establecen entre la idea de reminiscencia y escritura literaria, pues, siguiendo con Ricoeur, "la memoria reducida a la rememoración, opera siguiendo las huellas de la imaginación" (La memoria 21); huellas que no son otras que las construidas sobre el proceso de figuración.

Desde esta perspectiva, la memoria fabulada queda definida como aquella escritura de la reminiscencia que, sirviéndose del lenguaje, compone, con la libertad de saberse figuración, mundos fantasmáticos susceptibles de manipulación. Siendo la imaginación el almacén de imágenes, es la figuración el origen del movimiento que las configura, bien como recuerdo, bien como phantasmata, imago, pero, en cualquier caso, como proyección evocadora de lo ausente creada desde la subjetividad de la psique. Dominada por la voluntad de creación y el esfuerzo de evocación, la memoria fabulada es capaz de producir significados, otorgando un poder estético-literario a la palabra, que será capaz de elaborar una red de asociaciones semánticas y estructurales que figurarán mundos posibles. En definitiva, entendemos la memoria fabulada como una incisión que alcanza el centro de la configuración del sujeto y su relación con el entorno para elaborar un discurrir textual capaz de adquirir valores universales que excedan su referencialidad puramente sincrónica.

Como vemos, no es esta ni mucho menos una discusión teórica originalmente contemporánea, pues es una de las claves que ha circundado el fenómeno de la creación artística, en general, y la escritura, en particular (Addison; Serés Guillén; Ricoeur). Tampoco puede decirse que lo sea desde el punto de vista creativo, donde la confección literaria siempre ha tejido sus textos anudando imaginación y memoria. Y, sin embargo, la dicotomía invención/ reminiscencia que atraviesa como dialéctica la filosofía occidental pierde su peso en los estudios teóricos sobre la creación literaria en un momento donde la novelística está problematizando, precisamente, con la referencialidad autobiográfica y las escrituras del yo. De ahí la trascendencia de la propuesta anteriormente aludida de "figuraciones del yo" de Pozuelo Yvancos y su alusión platónica a la memoria. Más aún en el caso que nos ocupa, pues esta dicotomía es el corazón desde el que se bombea el oxígeno de la escritura de Eduardo Mendoza: "Mendoza escoge, de la literatura que conoce tanto como de la calle por la que transita, nombres sobre cuya base crear aquellos con los que bautiza a sus personajes, siempre resultones, siempre cómicos, siempre evocadores, siempre juguetones, siempre memorables" (Aparicio Maydeu 41). 
La memoria fabulada atraviesa su discurso, tanto en su relación con el mundo como en su relación con los textos, y es decisiva en la configuración de su narrativa, donde la literatura se nos presenta en su más pura esencia, como la figuración de imágenes dibujadas a partir de la capacidad evocadora de las palabras en discurso. El proyecto narrativo de Eduardo Mendoza radica en ese figurarse, en el pasar por la imaginación lo acontecido y en construir no lo que ha sido, sino la proyección formada en la fantasía de quien narra. Esto es, un mundo ficcional elaborado al unísono de la reminiscencia, que crea en la imaginación de autor y lector una memoria fabulada. La escritura de Mendoza es, en definitiva, aquella que remarca el fantasear, el valor de figuración que hay en la rememoración y donde verdaderamente se constituye una memoria colectiva armada sobre el poder evocador de la realidad modelada que en literatura da a luz lenguajes y voces. Incluso en sus textos ensayísticos no ficcionales, esta actitud de fabulador es la que conduce el discurso:

Conviene aclarar que este libro no es un estudio sobre el Modernismo ni sobre el período histórico al que corresponde; tampoco es un intento de reconstrucción verosímil de la vida cotidiana en la Barcelona de esa época. El propósito de este libro, en realidad, es plasmar en imágenes literarias y gráficas la noción que hoy tenemos de aquella Barcelona, en parte aún viva y presente en parte irremisiblemente perdida. En otras palabras: hemos querido recrear la Barcelona pretérita que la mayoría de los barceloneses guardamos en la imaginación, un poco a la manera de las pantomimas que entonces gozaron de tanto predicamento (Mendoza y Mendoza 11).

Dicho lo que antecede, solo me resta hacer algunas observaciones o advertencias al lector. La primera de ellas es ésta: que soy muy vulnerable a las impresiones que deja en el ánimo la memoria inconsciente y que al describir lo que recuerdo es posible que inadvertidamente deforme los hechos para adaptarlos a la impresión que recibí en su día sin percatarme de que la estaba recibiendo. Con esto quiero decir, dejando de lado este lenguaje pomposo, que los datos que doy no son de fiar (Mendoza, Nueva York 11).

Se presentan claros los ecos de la discusión previamente enunciada, donde ese guardar en la imaginación y las impresiones dejadas en el ánimo por la memoria se convierten en continente y contenido de su quehacer narrativo. El autor no lucha contra los ambiguos límites entre invención y reminiscencia, 
sino que se sirve abiertamente de las posibilidades que le ofrecen y, haciéndolas bailar, las reconstruye en forma de discurso. A lo largo de toda su trayectoria literaria, Mendoza ha ido posando ideas fugaces -como las citadas-que dejan ver el lugar creativo del escritor, en el que la memoria fabulada no queda en manos de la nostalgia, sino de su descubrimiento estético. Se percibe entonces la importancia de la fuerza de la palabra para la constitución de un mundo hecho de impresiones de la subjetividad. La constante vuelta sobre el punto desde donde se mira, la sacudida del velo impuesto por el ojo que observa, persiste en las reflexiones que el autor desarrolla sobre el universo artístico y subraya el objeto como imagen proyectada sobre la nostalgia de saberlo ausente, de reconocerlo pasado, sin que por ello pueda asentarse en su idealismo:

Hoy es difícil saber cómo debía de ser la infancia a finales del XIX. Los relatos que nos han llegado, escritos por personas que decidieron consignar sus recuerdos a una edad tardía, son siempre nostálgicos $\mathrm{y}$, por consiguiente, tienen más de emocional que de riguroso. Por otra parte, las fotografías infantiles de la época desprenden un hálito de melancolía que probablemente tiene más que ver con la calidad técnica de la fotografía y con la solemnidad excepcional del estudio que con el talante habitual de los retratados (Mendoza y Mendoza 15).

Son la mirada y el medio los verdaderos productores de la imagen en el espacio (el estudio): la distancia temporal y la cámara conforman la memoria no rigurosa sino emocional, no histórica sino figurada. Lo mismo ocurre con la literatura, medio revelador de la anisotropía que nos gobierna. Es en este punto (cuasi)nietzscheano que los estudios literarios, insuflados por los vientos de la posmodernidad, toman su camino hacia las profundidades de la manipulación histórica, sin percatarse de que lo que Mendoza pone sobre la mesa no es tanto la confrontación de una veracidad falseada, sino el interés por el poder connotativo del lenguaje artístico que hará posible la figuración de mundo y la universalidad literaria. Mendoza sitúa el valor del discurso estético en el halo que lo separa de lo biográfico y lo histórico, y que permite observar y explicar el entorno desde la distancia, desde una "atalaya imaginaria" (Aparicio Maydeu 72) que reporta el conocimiento de operar con material literario. Así lo afirma el propio Mendoza: 
en general un narrador no vive en el mundo ficticio de sus criaturas -precisamente su oficio le permite distinguir mejor que al común de las personas la diferencia que media entre lo real y lo imaginario-, y aun cuando extraía de sus propias vivencias los elementos que componen sus relatos, dichas vivencias pierden, en el proceso de transformación, su sentido original por lo que no hay forma más absurda de leer que rastrear en los sucesos narrados o en los personajes descritos, trasuntos de la vida del autor ("Baroja" 23-24).

En este contexto, uno de los amarres a los que se debe sujetar el análisis literario de sus novelas resulta el más evidente, pero el más fácil de soltar: el estatuto ficcional de su narración. Aquí se ha de tener muy presente aquello que ya ha quedado advertido por Paul Ricoeur y que Pozuelo Yvancos logra exponer en su Poética de la ficción: "la semántica del lenguaje poético no se construye sobre el valor de la referencia, sino sobre 'figuras', imágenes, que permanecen indiferentes a la oposición verdadero/falso que rige los enunciados de realidad con valor de verdad del lenguaje referencial" (Poética $71)^{5}$. Y es que la temporalización y la espacialidad de sus textos, unida a la modalidad discursiva de los mismos, arrastra al discurso teórico sobre Eduardo Mendoza hacia lugares del historicismo y los Cultural Studies que, no por menos válidos sino por sus distintos objetos de estudio, eluden los centros de la teoría literaria en los que algunos pretenden enmarcarse. Las referencias a la historia de Barcelona, España, Europa e incluso Estados Unidos, son abundantes y específicas, con un detallismo estético de elementos como el parte meteorológico, los productos del mercado y los actores secundarios que lo pueblan y que, consiguiendo su propósito, acaban por disimular la figuración en una literaturización de la memoria histórica. Como escritor, Mendoza se sirve de la que Greenblatt concebía como una economía simbólica, es decir, de los signos capaces de excitar emociones asociativas y susceptibles de ser manipulados gracias a la sensibilidad a la hora de jugar con las palabras, creando un sistema cultural figurado, sostenido sobre el lenguaje y las referencias no-verbales que lo envuelven.

La combinación de los periodos socialmente determinantes en la formación de una ciudad y un país llevados al telón de fondo de los relatos, junto a la pluma cronista que generalmente los orienta, invitan a la disección de 
fenómenos históricos en busca de la extracción de los manipulados quistes mendocinos ${ }^{6}$, y que, como bien se puede intuir, será generalmente la base de análisis de la comicidad posmoderna. Ahora bien, es cierto que la narrativa de Mendoza no es indiferente al momento sociocultural en el que se encuadra; ni lo es hacia el carácter retroactivo de cualquier forma de escritura. Pero a la pregunta de si los sucesos relatados y los datos históricos citados son verídicos o imaginarios, la respuesta de Mendoza es siempre una y la misma: "que la distinción carece de importancia, puesto que todo, en definitiva, es solo una novela" (La ciudad 10). En el trabajo de las formas de la memoria, en la aparente "voluntad de cronista" que diría Soldevila Durante, es en el que ha de buscarse el protagonismo de la figuración - del tiempo pasado y del espacio ausente- que domina la narratividad. Las características que definen la obra del barcelonés no encuentran su origen a propósito de las modificaciones de la Historia en mayúsculas, sino en los juegos diegéticos que van estableciendo historia y discurso gracias a las formulaciones que se justifican sobre la memoria narrativa heterodiegética y homodiegética. Es en el proceso de relatar desde la memoria fabulada donde encuentra su engarce la mayor parte de los elementos mendocinos: la intertextualidad, la transversalidad genérica, la hipertrofia, lo cómico, etcétera., que, gracias a las perspectivas internas y externas, las focalizaciones de consciencia e inconsciencia, logran su heterogeneidad narrativa. Las voces convocadas, narradoras y figurantes, van reconstruyendo memorias discursivas desde las que se accede a la historia, en minúsculas.

Ya con su primera novela, la reconstrucción de la verdad se aborda como una colección de voces y géneros que proyectan en la imaginación las figuraciones dibujadas sobre retazos de memoria del caso. La multiplicidad

\footnotetext{
Menudean, por ejemplo, las indicaciones sobre el desfase temporal en la citada edición de Aparicio Maydeu, en la que se combinan la reiteración de que "Mendoza se documenta para contextualizar, para evocar, no para reproducir, y su objetivo narrativo es sin duda el de ambientar, el de enmarcar, no el de reconstruir" (127), con las advertencias sobre los desajustes históricos con notas como la que sigue: "Se refiere a las pruebas nucleares que el Departamento de Energía de los Estados Unidos llevó a cabo en el Nevada Test Site, en el Estado de Nevada entre 1951 y 1992. La primera explosión atómica con éxito tuvo lugar, sin embargo, en el destierro de Alamogordo, Estado de Nuevo México, en julio de 1945, tres veranos antes del que concentra la acción novelesca" (139). O la más ocurrente: "En la jungla bibliográfica del autor belga [Georges Simenon], vaya uno a saber a qué novela se refiere el narrador, y si Prullàs sabía francés o, lo más probable, compró una de las últimas traducciones del autor" (166).
} 
discursiva y la disposición estructural de la novela permiten al autor recoger una colección de fragmentos discursivos y genéricos, una rica "textura", usando el término de Yang. Mendoza entra así al panorama literario con un conjunto de tarros herméticos en los que se guardan fragmentos de memoria aderezados con los más variados sabores a relato policial, folletín, crónica, melodrama, archivos periodísticos, políticos... En dos palabras: con una hemeroteca literaria sobre el "textimonio" del caso Savolta. Lo cierto es que, desde entonces, Mendoza ha venido demostrando un especial interés, o al menos una tendencia narrativa general, hacia formas discursivas con expectativas de verdad, como los diarios (de a bordo de Gurb y Horacio Dos, o de viaje de Pomponio Flato), los relatos autobiográficos (del detective sin nombre), las crónicas (de Onofre Bouvila y su Barcelona) y una significativa presencia epistolar (en La isla inaudita, El año del diluvio, Riña de Gatos o El rey recibe), con lo que la pragmática de la ficción vuelve a ser primera actriz en una escena establecida sobre las convenciones de lo histórico-documental, y cuya esencia se encuentra de nuevo fuera de los límites de la veracidad. En particular, tomando la "literariedad" como estatuto pragmático del que nacerá la ficción, encontramos fundamental el desdoblamiento del lector como receptor del texto. En este caso, el lector de las ficciones de Mendoza lo es por partida doble, pues en buena parte de los textos puede identificarse con el curioso entrometido que accede a una información en la que, en teoría, no estaba incluido; en un juego de correspondencias con buena parte de los protagonistas de Mendoza, que recorren a su vez el mundo ficcional husmeando en los rincones a los que no pertenecen. El fragmentarismo acaba afectando así a los conductores de la comunicación literaria donde también el receptor lleva a cabo un proceso de figurarse lector, encontrando en su imaginación las características que, impresas en el texto, conjeturan el destinatario textualizado.

El éxito de estos mecanismos internos de sus novelas es propiciado por una meticulosa selección de palabras que, preñadas de significación, son capaces de crear asociaciones no solo semánticas sino hermenéuticas. Nos enfrentamos a un relojero del lenguaje, en extremo cuidadoso en la colocación paradigmática y sintáctica de sus piezas que, finalmente, conseguirán producir tiempo. Eduardo Mendoza es un narrador consciente de las cualidades de sus herramientas, capaces de figurar en la imaginación un retrato impresionista, una "cabalgata de impresiones" que dirá sobre Pío Baroja en un artículo titulado precisamente "Tiempo y memoria" (50). Quizás sea justamente en aquellos lugares, en los que el barcelonés reflexiona sobre el porqué de su 
amor vascuence, donde con más claridad podemos explorar las ambiciones literarias de Mendoza. En las líneas dedicadas al avistamiento del escurridizo Nessi, como él mismo bromeará en uno de sus ensayos sobre el autor, se descubren destellos de su propio reflejo como novelista. Sobradamente ha quedado reconocida la relación maestro-discípulo entre Baroja y Mendoza, aquel que le dio la licencia para escribir novelas a este, le fascinó y mostró el camino literario: "Imitando a Baroja podía ser yo mismo" (Mendoza, "Baroja" 21). No tratamos de leer a Mendoza en clave de Baroja ni viceversa, pero, haciéndonos eco de la metodología mendocina, sí resulta útil contemplar en sus escritos sobre don Pío no las novelas del vasco, sino la impresión dejada por la mirada literaria del barcelonés que nos las presenta. Las similitudes entre los dos autores son tantas como las diferencias, pero es en la mirada de Mendoza donde siempre queda la complicidad entre dos novelistas que adoptan una actitud narrativa afín con la que acoger la tradición y, sin romperla, ponerla al día. Además de compartir bando en la batalla de la novela, lo que Mendoza distingue en Baroja es esa particular forma de lenguaje, en la que hemos reconocido en efecto su propio quehacer estético:

Pese a la aparente naturalidad, los diálogos de Baroja no lo son, aunque consiguen dar al lector la impresión de que los está oyendo. La gente no habla así. Al contrario, da muchas vueltas antes de ir directamente al asunto. Así solo hablan los personajes de Baroja, de Hemingway y de unos pocos más. Tampoco es un lenguaje teatral. Ni siquiera cinematográfico. Si alguna comparación admite es con el lenguaje radiofónico cuando las radios retransmitían seriales, episodios dramáticos y versiones teatrales adaptadas. No porque el lenguaje sea parecido, que no lo es, sino porque actúa del mismo modo en la imaginación del oyente o del lector. Con ligeras sugerencias para que la imaginación complete la escena (Mendoza, "Baroja" 61-62).

Y más adelante:

Nada de lo que se dice es trascendental, ni siquiera informativo. Pero el lector, al cabo de un rato se ve transportado a aquel hogar modesto. No solo las personas, sino los objetos no descritos surgen de la nada y adquieren presencia y volumen (Mendoza, "Baroja" 63).

"Cada palabra hace señas", diría Foucault (68). No solo la literatura de Pío Baroja y su pincel de brocha gruesa pero elocuente, sino las palabras 
que a ella dedica Mendoza nos señalan intermitentemente la idiosincrasia de este autor de ficciones, que asoma en la del ensayista. A la manera borgiana, Mendoza inventa a sus predecesores, donde "el impío don Pío" es nombrado gobernador. Comparemos ahora las anotadas consideraciones sobre Baroja con las reflexiones propias que prologan Una comedia ligera:

Desde el punto de vista literario no me interesaba tanto enjuiciar una época como describirla. Para conseguirlo, me propuse no relatar situaciones, sino reproducir lenguajes. Tengo buena memoria para las cosas que oigo (soy, en cambio, muy mal fisonomista) y he comprobado a menudo que ciertas palabras o expresiones resultan muy evocadoras para el oyente, que las había desterrado a un remoto rincón de sus recuerdos. En busca de estos sectores desterrados, y de todo lo que con ellos iba implícito, emprendí una larga y muy entretenida investigación (Mendoza, Una comedia 8).

Y después:

Con fragmentos de todos estos lenguajes construí el habla de los personajes de la novela. No pretendía al escribirla que ninguno de ellos se expresara con naturalidad, ni siquiera con verosimilitud, sino como actores inconscientes de una comedia colectiva (Mendoza, Una comedia 10$)$.

El paralelismo es notorio. Más allá de los diálogos barojianos, el discurso narrativo de Mendoza es enteramente una fabulación en la que intervienen múltiples discursos que van componiendo la gran orquesta lingüística que son sus novelas ${ }^{7}$. Géneros y estilos, sin perder la singularidad que los identifica (de hecho, subrayándola), son convocados al unísono gracias a los dos recursos determinantes en la personalidad literaria del autor: el punto de vista detectivesco-picaresco y el discurso indirecto libre. No por casualidad, hemos traído aquí Una comedia ligera, la cual es sin duda su

No hay más que enumerar algunas de las fuentes que lo acompañan en "su entretenida investigación" cada vez que aborda una novela: revistas de moda, del corazón, de cocina, literatura publicada, tebeos infantiles, prensa nacional, taurina, política, deportiva, películas y obras de teatro estrenadas, anuncios de marcas líderes del mercado, diccionarios de gitanismos y un largo etcétera. 
texto detectivesco por antonomasia, que supera a los demás en soltura y manejo de esta compleja voz narrativa. Allí, Mendoza se convierte en nuestro Flaubert, como lo renombra en su crítica a la novela Rafael Conte (1996). El desarrollo del discurso novelístico se alimenta de la maestría que el autor demuestra a la hora de componer una visión del mundo compartida entre Prullàs y el narrador, un artificio exclusivamente literario por el que acceder a la conciencia del otro. La subjetividad de la mirada se multiplica en estos juegos de transferencia discursiva que contaminan la voz narrativa, llevando a su máxima expresión el hecho de estar "hablando palabras del otro". En el caso de Una comedia ligera, la impostura que adoptan narrador y protagonista en sus respectivos lugares de acción acaba por configurar un discurso en el que se funden lo cinematográfico y lo teatral con lo novelístico, en una mise en abyme detectivesca que organiza la trama bajo un continuo movimiento entre discursos. El lenguaje en esta novela se desliza desde la figuración del mundo de la burguesía catalana hacia las proyecciones de un discurso hollywoodiense, chispeante y afectado, envueltos ambos en la endémica voluntad de placidez sosegada con la que contener los ecos de una guerra que aún siguen sonando. El artificio de este juego literario atrapa al lector que observa desde esa mirada indirecta libre los más diversos actos de habla que en el texto se producen, haciéndose patentes estos actores inconscientes y su comedia colectiva.

En definitiva, el lector es capaz de construir un mundo a través de la palabra y ese catálogo de voces impostadas sobre las que se construye una escena y se presentifica un ambiente. Eduardo Mendoza aprovecha los ecos que el lenguaje es capaz de producir y sobre los que se reproducen imágenes reales, no por su veracidad, sino por su singularidad semántica y su carácter universal adquirido en su transformación en ingrediente literario. Pues, siguiendo a Bergson en Materia y memoria: "Para evocar el pasado bajo la forma de imagen, es preciso poder abstraerse de la acción presente es preciso saber apreciar lo inútil, es preciso querer soñar. Quizás sólo el hombre es capaz de un esfuerzo de esta clase" (101). De nuevo, la memoria fabulada entra en juego: escritura ella misma "memorable", la de Eduardo Mendoza es una industria productora de idiolectos e imágenes que se pintan como figuraciones con las que el autor logra, sirviéndonos de la idea de Joseph Addison, herir la imaginación del lector gracias a la hábil manipulación del lenguaje como sistema semiótico. Los objetos (artísticos y de consumo) y los caracteres (poderosos y marginales) son dibujados en el lenguaje y en él funcionan como aquello a lo que se aferra la memoria de una época. La 
literatura puede acoger en su seno toda una fábrica de objetos capaces de evocar significaciones más allá de su ser-objeto y de otorgar valor a lo inútil para reproducir sentimientos de época así como sentimientos del yo. Las palabras hacen señas porque en ellas se incorpora una tradición estética, consciente o inconsciente, pero generadora siempre de una forma estar en el mundo que Mendoza va adaptando a sus intereses narrativos. Así, la memoria fabulada en Mendoza, más que la memoria histórica, se convierte en la memoria de sus lecturas sobre las que el autor aplicará su pluma, como así aplicaba don Quijote su lanza de caballero: "Y así, después de muchos nombres que formó, borró y quitó, añadió, deshizo y tornó a hacer en su memoria e imaginación, al fin le vino a llamar Rocinante, nombre a su parecer, alto, sonoro y significativo de lo que había sido cuando fue rocín, antes de lo que ahora era, que era antes y primero de todos los rocines del mundo" (Cervantes 32).

Desde los estudios formalistas y estructuralistas, el análisis de la intertextualidad en la teoría literaria ha profundizado en las relaciones internas establecidas entre textos, explicando la incorporación y la transformación formal y semántica de los precedentes. El caso de las relaciones de Eduardo Mendoza con la tradición ha sido singularmente trascendental dado lo que supuso La verdad sobre el caso Savolta (1975) para la novela española en general y para el novelista en particular. La transgresión del barcelonés fue ser un no-transgresor, optar por una opción narrativa que reconsiderara la tradición realista de la novela del XIX y los distintos moldes de la cultura popular. Pese a que toda innovación, incluidas las más vanguardistas, trae aferrada una tradición ${ }^{8}$, la voz narrativa mendocina se aferra a los modelos sobre los que camina, fingiendo incluso desaparecer tras ellos. Su artificio narrativo se define como una receta en la que se amasa, se estira y se corta la tradición literaria para aderezarla con los finos toques, suaves y refrescantes, añadidos en su cocina personal. El buen oído, de espectador y de lector, otorga a Mendoza la facultad de disponer de una permanente "memoria textual":

Subyace siempre en la narrativa del autor una permanente memoria textual de sus lecturas de obras ajenas, que con asiduidad se refleja en una suerte de apetecidos pastiches que no pretenden ocultar que lo

\footnotetext{
Volviendo a T. S. Eliot: "Tradition involves the historical sense; [...] the historical sense compels a man to write not merely with his own generation in his bones, but with a feeling that the whole of literature of Europe from Homer and within it the whole of the literature of his own country has a simultaneous existence and composes a simultaneous order" (37).
} 
son y que, lejos de restarle personalidad a su estilo, verdaderamente lo definen, a la vez que le permiten al lector avezado complacerse en el ejercicio de tratar de reconocer en cada caso los mencionados juegos de transtextualidad, ecos, remedos, paráfrasis, ejercicios de imitación, homenajes o evocaciones que el autor desperdiga en sus textos (Aparicio Maydeu 38).

Su quehacer estético, translúcido siempre en sus influencias -y justamente traslúcido, pues la aparente superficialidad de las referencias presentadas al lector esconde una gran profundidad de campo-, juega con las problemáticas teóricas que implica la conjugación de innovación y repetición. De manera que es hora de reparar en la otra cara de la moneda: la memoria. Habiendo insistido en el particular proceso de figuración por el que Mendoza destaca su sobrenombre fabulada, la consciencia de la manifestación de lo pasado en el presente en forma de recuerdo es igualmente determinante en su discurso literario. No solo en sus reflexiones, de las que ya se ha podido colegir su carácter "textimonial", sino también en la construcción de su ficción coexiste la voz que nos remite a un artificio conocido con un grado de desviación de lo que fue frente a lo que es. El género policíaco, el Bildungsroman, el picaresco o el estilo realista, el naturalista y el dramático son convocados en las novelas de Eduardo Mendoza, precedidos por la apostilla del "como si". No obstante, la facilidad primera con la que parece reconocerse la estructura genérica que sujetan sus obras requiere de una pronta matización, ya sea en virtud de un mecanismo de subversión, de fusión, de transformación o de todos ellos al mismo tiempo. La memoria textual de autor y lector se encuentran siempre en movimiento; su discurso despierta en la conciencia de quien lo lee unas fórmulas y unas voces que se tornan figuraciones en tanto se reconocen como una impresión trastocada desde el presente:

Consciente o inconsciente, la obra de ficción es, en buena medida, un ejercicio combinatorio de elementos tomados de la tradición y puestos al servicio de una historia que, aquí sí, ha de ser sincera y genuina. Ya he dicho que estos referentes pueden ser inconscientes, y ahora lo reitero: la influencia más poderosa es la menos sabida, precisamente porque opera en el estrato profundo de donde surgen las historias. [...] En definitiva, la tradición no es una línea recta ni única. Si se me permite una metáfora repulsiva, es un río con muchos afluentes (Mendoza, "El escritor" 16-17). 
La liquidez que la posmodernidad ha otorgado a la noción de tradición -venida de las reflexiones traídas del neobarroco hispanoamericano, que el propio Mendoza recoge en este ensayo sobre la relación del escritor con la crítica- es particularmente significativa en las reflexiones del autor sobre la creación literaria, cuya insistencia en aquellos referentes "inconscientes" que empapan la tinta del escritor declara una concepción de lo literario fundada sustancialmente sobre el componente de la memoria. Lo literario se convierte en una genuina composición de lecturas anteriores que, conscientes o inconscientes, son traídas a la memoria por la imaginación, cuyas posteriores asociaciones son precisamente las que actualizan el texto en cada lectura crítica. Así, la evocación de referentes en la memoria, lejos de reconocerse labor exclusiva del creador, lo es igualmente del lector, quien aportará un valor personal al texto escrito. Y es que el papel activo que la memoria ejerce en la constitución de lo literario (sea desde el lado de la escritura como del de la lectura) es una de las claves que recupera el autor en sus escritos sobre literatura, pues la volubilidad de aquella plancha de cera ante la sucesión de impresiones es la que permite la perpetua recreación estética. Un escritor es, antes que nada, un lector. Obsérvese cómo aborda el proceso de la creación literaria al compás justamente de aquella idea agustiniana de la memoria y remitiendo a la anécdota del joven Goethe que se enfrenta a la traducción de la Biblia:

El trabajo, sin embargo, rinde un dividendo inesperado: al leer el Antiguo Testamento con la atención puesta en los laberintos del idioma y no en los sucesos narrados, se impregna de una historia que, sin saber cómo, le permite comprender la relación existente entre lo que hasta entonces ha acumulado en su corta trayectoria vital: lo que ha leído, oído, visto y sentido, lo elevado y lo trivial, en suma, las nociones aprendidas o, en palabras de san Agustín, "las imágenes de las cosas sentidas", como en una revelación, se estructuran y adquieren la razón de ser que constituyen la personalidad y la vivencia intransferible del autor (Mendoza, "Breve informe" 31).

Se establece entonces la completa conexión entre reminiscencia e invención que cimentará los procesos de lectura y escritura como un ciclo de memorias textuales que -siguiendo con la "metáfora repulsiva"- fluyen voluntaria e involuntariamente en la imaginación. Es el valor difuminado de la memoria lo que incide en la comunicación literaria pura, previa a la mirada analítica y sistemática del liseur de romans de Thibaudet. Sin necesitar la referencia unívoca sino la impresión dejada por la asociación, el ejercicio de lectura 
evoca desde un discurso cerrado, una memoria textual abierta. De nuevo, nos movemos en el dominio de la percepción que doblegaba a lo histórico y que ahora supedita a la retórica estructuralista. La memoria funciona sobre la subjetividad de la lectura pasada, de las impresiones dejadas en el lector, más allá de las líneas que quedan escritas en la hoja por el autor. No es el libro sino la lectura fabulada en la memoria textual lo que el barcelonés utiliza en su narración. En distintos momentos, el propio Mendoza asegura no haber buscado las lecturas que recuerda haber hecho (y los resultados decepcionantes que ya afirma haber experimentado), sino que lo que recupera "es la memoria de lo que en su momento representaron aquellas lecturas" (Las barbas 10) ${ }^{9}$. Este diálogo en diferido que establece el autor con la tradición personal resulta fundamental para entender su carácter narrativo, pues la evidente intertextualidad sobre la que Mendoza encamina su discurrir se funda sobre su recepción y sobre las razones por las cuales permanecen impresas en su memoria.

Ahora bien, no se debe concluir que la narrativa mendociana se desarrolle al amparo de la flexibilidad y la laxitud de una rememoración engañosa. Todo lo contrario. Eduardo Mendoza es, ante todo, un lector provechoso. $\mathrm{Su}$ escritura anida en voces ajenas, singulares y memorables, concretas y rigurosas, y solo gracias a la impostura es capaz de generar un causal (que no casual) sistema de asociaciones tan elocuentes que no necesitan el desvelamiento de cada una de sus fuentes para conseguir en el lector una figuración compleja y completa de textos antes dormidos en el imaginario. La meticulosidad del proceso de creación de Mendoza es palmaria, desde su estudio de hemeroteca hasta el acoplamiento de cada una de sus frases; es, como quisimos presentarlo, un escritor artesano, heredero de los saberes de sus maestros, los cuales adapta a las características de su taller, donde trabaja desde el origen mismo del objeto artístico conociendo aquellas piezas sobre las que ha de armar su trabajo. Solo siendo un experto de su tradición, como lo es Mendoza, se es capaz de reproducirla valiéndose de un pulso personal. Él mismo reconoce esto cuando alude a su quehacer mimético:

\footnotetext{
Pensemos, especialmente, en aquellas lecturas de la infancia que pueblan el mundo narrativo del Mendoza adulto. La "infancia recuperada" que ya decía Fernando Savater con los tebeos, las novelas de aventuras e incluso los episodios de la Historia Sagrada se manifiestan en la obra de Mendoza, no tanto en forma de referencias como en formas de construcción discursiva. Es aquello que las hace memorables y provocativas para la imaginación lo que el novelista acoge de ellas y transmite a sus textos.
} 
Soy incapaz de empezar a escribir si antes no he encontrado una voz que impostar; siempre he pensado que no tengo voz propia y que solo funciono cuando imito, como esos epígonos que al emular a Pavarotti son capaces de dar el do de pecho sostenido, una nota que no alcanzarían jamás si cantaran a su manera, sin referentes (cit. en Moix 26).

De forma que, imitando, o mejor, impostando a sus referentes, consigue alcanzar el "do de pecho" que presenta a los espectadores, partícipes de la evocación a través de su individual propuesta de figuración. En este punto, hay un elemento determinante a la hora de entender la concepción de tradición literaria en los artistas contemporáneos, que tiene que ver con cómo la episteme posmoderna le ha otorgado un funcionamiento en base a la mirada simultánea y heterogénea de formas y contenidos. Textura, mixtura, collage y pastiche son solo algunos de los términos que se vienen usando a la hora de situar las características narrativas de Mendoza y su riqueza lingüística. Las consecuencias de este tipo de categorías, donde el hibridismo concedido por la relativización que ha impuesto la posmodernidad comprometerá una pérdida de significación histórico-semiótica, no escapará al quehacer literario y crítico de Mendoza. La exposición de la memoria textual que rodea todo objeto estético posmoderno permite una liberación radical del tratamiento de las formas que se encuentran ahora al servicio de la voluntad de creación de su autor y receptor, pues el lenguaje posmoderno desvela la vacuidad de los signos para operar con simulacros. Nos encontramos inmersos en "una sociedad de la imagen o del simulacro y de la transformación de lo "real" en una colección de pseudoacontecimientos" (Cultura y simulacro 107).

Uno de los lugares que mejor ha evidenciado esta concepción del lenguaje ha sido el arquitectónico, donde fue tempranamente gestada la expresión de la posmodernidad. Por ello, el interés de Mendoza por la arquitectura estimula tímidos acercamientos que, sin embargo, avivan la reconsideración de lo posmoderno desde un ángulo privilegiado y no estrictamente literario, del que damos parte. Las líneas que siguen pertenecen a un artículo que examina la obra teórica de su amigo Ignasi de Solà-Morales:

Un sistemático saqueo formal, la historia se convierte en simple proveedora de materiales para el gran mercado de la nueva producción de edificios, lo que da lugar a "la angustiosa situación de disponer aparentemente de todas las lecciones de la historia pero de carecer, en cambio, de cualquier otra pauta que no sea la del talento personal a la 
hora de reproducirnos una imagen metafórica de su propio recuerdo" [...]. Este descalabro produce al mismo tiempo "una nostalgia del orden clásico [...] que se evoca únicamente como ilusión y como memoria". La consecuencia: el "historicismo reaccionario" y un "comercialismo sentimental" de que en la actualidad adolecen buena parte de los edificios llamados a desempeñar un papel emblemático ("El arquitecto" 25).

Las consideraciones sobre el valor histórico que ha marcado al objeto arquitectónico, ante las propuestas nacidas del golpe a la identidad que supusieron la Primera y Segunda Guerra Mundial, dan pie a Mendoza a escoger unas significativas citas para acompañar un discurso propio que se asoma a las preocupaciones estéticas del narrador de ficciones. Como las nuevas respuestas arquitectónicas, las figuraciones que nos aporta la memoria fabulada fácilmente pueden aparecer como imágenes vacías, impresiones sin objeto que las imprimiera y que, estudiadas desde la contemporaneidad, revelan ese "comercialismo sentimental" con el que comunica la manipulación de los símbolos culturales del escritor. Una de las claves de esta memoria fabulada es la conexión misma con el artificio del simulacro posmoderno. La agudeza del autor consiste en recoger también esta tradición y, haciéndola suya, problematizar con sus materiales. De esta conciencia de simulacro se valdrá Mendoza en su ficción y dará cuenta en sus ensayos, nuevamente dejando de lado la voz dogmática para discurrir junto al lector sobre estas formas que, escindidas de su razón de ser, se conforman como símbolos ${ }^{10}$. Se explica así que el modernismo constituya uno de los motivos recurrentes del autor, pues en él se aúnan el artificio, la construcción de una identidad, la seña barcelonesa y la ampulosidad. Todas estas son cualidades necesarias para artistas capaces de "crear de la nada", como dirá el autor, y que se proyectan en la literaturización misma. Más aún, existe un agudo ejercicio de duplicidad en el juego de creación de una identidad literaturizada, sufragada a su vez por el impulso de creación de una imagen que responda a una figuración de memoria fabulada:

10 No por casualidad tendrá una evidente representación en la construcción de espacios narrativos. Las Exposiciones Universales, los palazzi venecianos, el bazar, serán lugares de reflexión sobre la significación y su relación posmoderna a partir de la construcción de los espacios del no-ser, como proyecciones fantasmáticas del imaginario y su resemantización en la posmodernidad a partir del contexto del museo. 
No era esta cualidad, sin embargo, la que ahora llamaba la atención de los barceloneses y atraía su interés, sino las huellas de un pasado olvidado y una identidad casi perdida. Poco a poco los edificios fueron siendo restaurados, al igual que los muebles y los objetos [...] muy pocos habían sobrevivido sin perder su personalidad y su sentido. Rescatados como piezas casi arqueológicas, quedaron como testigos mudos de un mundo que había dejado de pertenecer a la memoria colectiva de la ciudad, de una época cuyo pulso rebasaba en buena parte los límites de la ciencia histórica para adentrarse en el campo de la imaginación (Mendoza y Mendoza 159).

Conectado con el mencionado esfuerzo creativo bergsoniano, la figuración de la memoria se presenta como el mecanismo para reconocer(se) y del que pueda nacer una identidad sobre la que operar. Estamos de nuevo ante un elemento recurrente en las narraciones del autor, la búsqueda de un pasado glorioso fundado sobre lo legendario, esto es, de un lenguaje primigenio, verdadero, que contenga la identidad (en todos sus sentidos) ahora perdida. Para ello, Mendoza se sirve del acervo literario proporcionado por una educación religiosa, donde los mitos fundacionales, acompañados de una peculiar hagiografía, despliegan distintos milagros en el propio desarrollo de la trama. Así, Mendoza levanta su narración sobre un juego semiológico organizado en los valores de lenguaje que circundan la explicación del mundo y del sujeto, eso sí, con un fuerte componente de invención y reminiscencia propio del universo ficcional del que forma parte. En él resonará la frase lapidaria sobre Prùllás "sin otro futuro que la nostalgia" -que dialoga con la de Vázquez Montalbán: "la nostalgia es la censura de la memoria" (1979)-, que bien sirve de epílogo al proyecto narrativo, sin otra salida que una constante revelación de nuestra memoria fabulada ${ }^{11}$.

Como se ha podido observar durante este artículo, los paratextos escritos por Eduardo Mendoza han demostrado una constante preocupación sobre la creación literaria como figuración de una memoria fabulada armada sobre

11 Incluso, la idea de la confección de unas memorias autobiográficas no ha logrado vencer a la naturaleza de la novela y a la ficción como únicas formas de representación posibles para el escritor. Las tres leyes del movimiento es el más reciente proyecto narrativo del barcelonés y no podía ser de otro tipo sino ficcional. En él nos lega una memoria textual situada en el tiempo habitado por el escritor, pero sin constreñirse a una univocidad interpretativa. Es la declaración oficial de que la de Mendoza nunca una voz estable, sino un compendio de "discurrires, digresiones e impresiones" de una poliédrica memoria textual, fabulada y festiva. 
distintos lenguajes y la capacidad que estos tienen de crear imágenes textuales significativas, siguiendo una noción de literatura estrechamente vinculada a aquella idea clásica de memoria como terreno en la phantasía. En el ejercicio de recolección de impresiones llevado a cabo por el autor, hemos querido enfatizar -dado que así lo hace Mendoza- el poder transformador de su lugar de almacenaje y presentar la escritura como una reconstrucción del recuerdo fantaseado, que la vida y el arte han ido depositando en la imaginación y la memoria, y que será puesto en movimiento gracias al mecanismo estético de figurar(se). En definitiva, el mundo narrativo de Mendoza se conforma gracias al organismo de memorias textuales que se entrecruzan desordenadamente para adquirir una presencia simultánea como figuración. Los textos se reproducen y reconocen en el impulso semiológico de otorgar un valor genuino al signo con el que jugará el escritor. Recorrer las novelas de Mendoza es adentrarse en el tortuoso camino de la impostura, capaz de generar asociaciones tan rápidamente como de destruirlas, haciendo uso de una conciencia de ambas, memoria y de fabulación para que, al convocar los discursos y voces, no aparezcan sino las imágenes de las mismas. O concluyendo con las palabras del autor: "Al tratar de exponer una conclusión a lo que acabo de contar tengo la sensación de haber falseado el argumento. No al escribirlo, sino al recordarlo. Siempre ocurre así: es como si al invocar unas imágenes del pasado, estas se resistieran a venir y enviaran en su lugar un sucedáneo. Todo es igual, pero no es lo mismo" (Las barbas 147).

\section{BIBLIOGRAFÍA}

Addison, Joseph. Los placeres de la imaginación. 1712. Madrid, Visor, 1991.

Álvarez Méndez, Natalia. "Geografías de la memoria y otros territorios fabulados". El arte de contar. Los mundos ficcionales de Luis Mateo Díez y José María Merino. A. Casas y M. Encinar (coord.). Madrid, Cátedra, 2017, pp. 133-155.

Aristóteles. "De memoria et reminicentia”. Parva Naturalia. J. A. Serrano (ed.), Madrid, Alianza, 1993.

Auerbach, ERICH. Mímesis: la representación de la realidad en la literatura occidental. Ciudad de México, Fondo de Cultura Económica, 1950.

Baudrillard, Jean. Cultura y simulacro. Barcelona, Kairós, 1978.

Bergson, Henri. Materia y memoria. 1896. Buenos Aires, Cactus, 2013. 
Bou, EnRIC. "Eduardo Mendoza: retratos de Barcelona, la (re)invención de la ciudad". Eduardo Mendoza y la ciudad de los prodigios. Cañete Ochoa (coord.). Alcalá de Henares, Publicaciones Universidad de Alcalá, 2017, pp. 35-48.

Cercas, Javier. El punto ciego. Barcelona, Literatura Random House, 2016.

Cervantes, Miguel de. Don Quijote de la Mancha. 1605. Barcelona, Alfaguara, 2005.

Cilleruelo, Lope. Obras completas de San Agustín. Cartas (I). Madrid, Editorial Católica, 1986.

Colmeiro, José. Manuel Vázquez Montalbán: el compromiso con la memoria. Londres,

Tamesis Books, 2007.

"Memoria, ideología y heterodoxia: Contra el pensamiento hegemónico". MVM:

Cuadernos de Estudios Manuel Vázquez Montalbán 3, 2017, pp. 3-24.

Conte, Rafael. "Una comedia ligera. Eduardo Mendoza”. ABC Literario 7, 1996.

Diccionario de Autoridades. "Memoria”. Diccionario histórico de la lengua española. Web.

Disponible en: https://apps2.rae.es/DA.html

Díez, Luis Mateo. "Territorios de la imaginación y la memoria". Actas del II Congreso de

Literatura Contemporánea. J. Balcells (coord.). Burgos, Instituto Castellano y Leonés de la Lengua, 2005, pp. 19-22.

ELıot, T. S. "Tradition and the Individual Talent”. 1919. Perspecta 19, 1982, pp. 36-42,

Foucault, Michel. Las palabras y las cosas: una arqueología de las ciencias humanas. Buenos Aires, Siglo XXI, 1996.

Greenblatt, Stephen. Culture: Critical Terms for Litrerary Study. Chicago, University of Chicago Press, 1995.

Moix, Llàtzer. Mundo Mendoza. Barcelona: Seix Barral, 2006.

Mendoza, Carmen y Eduardo Mendoza. Barcelona modernista. Barcelona, Planeta, 1989.

Mendoza, Eduardo. Nueva York. Barcelona, Ediciones Destino, 1986.

La ciudad de los prodigios. Barcelona, Seix Barral, 1986.

Una comedia ligera. Edición de Javier Aparicio Maydeu. Barcelona, Seix Barral, 1996.

"El arquitecto meditabundo". Revista de libros de la Fundación Caja Madrid 95, 2004, 24-26.

"El escritor y la crítica". La verdad sobre el caso Mendoza. José Saval (coord.).

Madrid, Editorial Fundamentos, 2005, pp. 15-18.

"Baroja: Tiempo y memoria". Revista de libros 120, 2006, pp. 50-51.

"Breve informe sobre la lectura". Revista de libros 117, 2006, pp. 31-34.

"Entrevista Eduardo Mendoza". El Cultural (web), 30 de octubre de 2015, consultado

el 21 de noviembre de 2021, disponible en:https://elcultural.com/El-secreto-de-la-modeloextraviada.

Las barbas del profeta. Madrid, Fondo de Cultura Económica de España, 2017.

Baroja y yo: por qué nos quisimos tanto. Navarra, Ipso Ediciones, 2019. 
Navajas, Gonzalo. Más allá de la posmodernidad. Estética de la nueva novela y cine españoles.

Barcelona, EUB, 1996.

Pavel, Thomas. Fictional worlds. Boston, Harvard University Press, 1986.

Platón. Diálogos VI; Filebo. Madrid, Gredos, 1992.

Teeteto. Buenos Aires, Editorial Losada, 2006.

Pozuelo Yvancos, Jose María. Poética de la ficción. Madrid, Síntesis, 1993.

Figuraciones del yo en la narrativa. Javier Marías y Enrique Vila-Matas. Valladolid, Cátedra Miguel Delibes, 2010.

“"Figuración del yo’ frente a autoficción”. La autoficción: reflexiones teóricas. Ana Casas (coord.), Madrid, Arco Libros, 2012, pp. 151-173.

“Celama. El territorio literario de Luis Mateo Díez”. Zenda. 26 de enero de 2019, consultado el 21 de noviembre de 2021, disponible en: https://www.zendalibros.com/ celama-el-territorio-literario-de-luis-mateo-diez/

Ricoeur, Paul. Tiempo y narración I. Ciudad de México, Siglo XXI, 1995.

La memoria, la historia, el olvido. Madrid, Trotta, 2003.

Sí mismo como otro. Ciudad de México, Siglo XXI, 1996.

Riffaterre, Michael. Fictional Truth. Baltimore, Johns Hopkins University Press, 1990.

SAntana, Mario. "Eduardo Mendoza y la narrativa de la Transición”. La verdad sobre el caso

Mendoza. José Saval (coord.), Madrid, Editorial Fundamentos, 2005, pp. 19-32.

SAval, José. La ciudad de los prodigios de Eduardo Mendoza. Madrid, Síntesis, 2003.

El triunfo de un luchador incansable. Madrid, Síntesis, 2004.

SAVAter, Fernando. La infancia recuperada. Madrid, Taurus, 2017.

Serés Guillén, Guillermo. "El concepto de fantasía, desde la estética clásica a la dieciochesca". Anales de Literatura Española 10, 1994, pp. 207-236.

Soldevila Durante, Ignacio. "Ficciones de la memoria: Una comedia ligera de Eduardo Mendoza”. España contemporánea, 1998, pp. 103-106.

Soubeyroux, JAcQues. "De la historia al texto: Génesis de La verdad sobre el caso Savolta de

Eduardo Mendoza". Actas del XI Congreso de la Asociación Internacional de Hispanistas. Juan Villegas (coord.), California, University of California Press, 1992, pp. 370-378.

Thibaudet, Albert. Le liseur de romans. París, Les Éditions G. Crès et cie, 1925.

Vázquez Montalbán, Manuel. A fondo, Entrevistado por Joaquín Soler. RTVE. 1979

YANG, Chung-YING. Eduardo Mendoza y la búsqueda de una nueva novela policíaca española.

Madrid, Pliegos, 2000. 